\title{
A Comparison of Seattle's Building Tune-up Process
}

\author{
Sharon Stukalo ${ }^{1}$ \\ ${ }^{1}$ Sustainable Building Science Technology Program, South Seattle College, USA \\ Correspondence: Sharon Stukalo, Sustainable Building Science Technology Program, South Seattle College, \\ USA. E-mail: sstukalo701@southseattle.edu
}

Received: December 14, 2018

doi:10.5539/jsd.v12n2p123
Accepted: March 2, $2019 \quad$ Online Published: March 30, 2019

URL: https://doi.org/10.5539/jsd.v12n2p123

\begin{abstract}
The Building Tune-up process has been in incorporated into the mindset of building owners in Seattle. Every five years this process needs to be implemented for all buildings that are over 50,000 square feet. Boulder, Colorado, and New York City, New York, have had similar programs in place longer than Seattle has had its program. There are many similarities between all three programs in regards to lowering carbon emissions through building maintenance and upgrades. Each city has specific bench marking goals as per what size of the building and when their specific tune-up should occur. There are also similar concerns from both building owners in regards to the costs of building upgrades versus the benefits that align with improved building performance. Within all three cities, tenants also share similar concerns mostly about increased rent due to having these buildings be improved. Both Boulder, Colorado, and New York City, New York, despite population size or location, have seen dramatic carbon decreases due to their tune-up policies being in effect. This gives great promise that Seattle's similar tune-up process will also yield positive results.
\end{abstract}

Keywords: building tune-up, bench marking, carbon, emissions, Boulder, New York, NYCEEC, ordinance, performance ordinance, Seattle, SMC 22.930

\section{Introduction}

Many know of Seattle as the "Emerald City" with a booming economy and a healthy construction industry. However, with more and more people living and working in Seattle and the surrounding area every year, it has been imperative to focus on how people are affected by buildings and how those buildings affect the environment. Seattle is currently at the forefront of the "green city movement" and vocal in matters, they have passed ordinances to become a more carbon-neutral community by 2050. "The City of Seattle is aiming for an 82 percent reduction in building-related emissions by 2050 and a 45 percent reduction in commercial building energy use by 2050 to help achieve that goal"(Coven). As a result of Seattle's goal, all commercial buildings that are 50,000 square feet or greater need to "tune up" their building systems every five years. The idea for this "tune up" process is to have Seattle encourage changes in how building owners should operate their respective buildings. The thought of creating change through the implementation of these policy changes is a great idea and an outstanding goal to reach. This brings up the question, if this is the most effective way to achieve carbon reduction goals in comparison to other cities, such as Boulder, Colorado or New York City, New York?

\section{Environmental Policy Issue}

To help combat climate change and carbon emissions, Seattle became creative with its idea for its commercial buildings through the Seattle Municipal Code (SMC) 22.930. SMC 22.930, Building Tune-ups, states that all commercial buildings in the City of Seattle need to be in compliance with the build tune-up process by certain dates for building sizes. Building sizes are taken into consideration while focusing on the tune-up process. Buildings larger than 200,000 square feet need to be in compliance by March 1, 2019; while buildings 100,000 to 199,999 square feet in compliance by October 1, 2019; buildings 70,000 through 99,999 square feet in compliance by October 1, 2020; and buildings 50,000 to 69,999 square feet need to be in compliance by October 1, 2021(About Building Tune Ups, 2018). The building tune-up process does not including living spaces or garages.

"Building Tune-Ups involve assessment and implementation of operational and maintenance improvements to achieve energy and water efficiency. Examples of operational fixes include changes to thermostat set points, or adjusting lighting or irrigation schedules. Tune-ups also review HVAC, lighting, and water systems to identify 
needed maintenance, cleaning or repairs - for example replacing faulty sensors or fixing problems with an economizer" (About Building).

The building elements to be assessed in a tune-up, and the associated corrective actions were designed to incorporate actions that taken together would, on average, reduce energy use between 10 to 15 percent and payback in utility bill savings in 2 to 3 years.

\section{Major Contending Views}

One focus was to examine whether a citywide building tune-up process was feasible for building owners in Seattle whose buildings were both commercial and multifamily. The major contending view about the Seattle Tune-Up Program is the overall cost of the tune-up process for commercial landlords. This concept was explored prior to implementing the building tune-up process. There are two main schools of thought that have been explored by building owners. The first thought is that there is no reason for building owners to invest in upgrades to their buildings because they are not the ones that will see decreased utility costs. The second thought is that those owners that do invest in upgrades to their buildings can increase rent due to having lowered utility costs. It was noted by Mallory that " there were concerns about owners charging higher rents if they make upgrades and therefore raising costs on tenants but lowering tenant utility bills were identified by housing providers as an important issue for ensuring total housing availability" (Mallory, Pg. 8).

Household availability, high rents, and high utility bills are a major concern for any person or family living in or thinking about moving to King County. For many families increases in rent due to building upgrades can and will be problematic for their monthly budget. Many feel that the commercial landlords can and will pass the costs of the building tune-up to the tenants in the form of "common area maintenance charges", "operating expenses", or extra fees. Currently "... a commercial tenant should expect that its commercial landlord will likely pass through the tenant's proportionate share of the costs associated with the building tune-ups program to the extent permitted under the lease" (Marchesano). Since the utilization of Seattle's building tune-up program, there has been little negative media coverage and at this moment little-publicized outcry to any increased costs that building owners or tenants face.

\section{Author's Perspective}

The author of this paper has a unique perspective of watching Seattle Municipal Code (SMC) 22.930 in action from a professional viewpoint. From understanding and experience on commercial and industrial building sites, SMC 22.930 will do nothing but help Seattle and provide a template for other cities and in the future other states to follow. This Code helps "sick buildings." The term "sick building syndrome" (SBS) is used to describe situations in which building occupants experience acute health and comfort effects that appear to be linked to time spent in a building, but no specific illness or cause can be identified" (Indoor Air Facts). Often building occupants may experience symptoms including headaches, coughs, fevers, or muscle aches. No two people may experience the same symptoms. Some causes of "sick buildings" may be from poor or dirty ventilation systems or possible chemical contaminants within the building.

SMC 22.930 will also provide more jobs for those who are joining the burgeoning industry of building "tune-up" providers. This will help Seattle's economy and help create a new area for possible career growth. At the same time,when this Code is in full effect there will be monetary fines in place for building owners that are not in compliance with the new code. This could give more incentive for the building to be brought up to code and stay within code, without any major catastrophes being the cause for change. As a result, this may be a great long-term first step for Seattle to combat carbon emissions and change the current mindset of both building owners and tenants.

\section{Relevant Evidence}

With the current job market and economy in the Pacific Northwest, our current goals for environmental recovery, and the clean energy goals, it is little wonder that many feel that Seattle and the surrounding area is a great place to live, work, and raise families. As of 2017, there is an estimated 700,000 people living in Seattle; in comparison, Boulder, Colorado has approximately 107,000 people and New York City, New York has over $8,622,000$ people (Data Access). This is relevant due to both Boulder and New York City having similar programs for their building's health, even though their population size and city size in comparison to Seattle's is quite different.

"New York City's similar "tune-up" requirement, and a recent U.S. Department of Energy analysis found that New York City's program led to almost 6 percent energy use reduction, almost 10 percent carbon emissions reduction, and the creation of over 7,000 jobs, all in the first three years of implementation" (Willmott). 
The New York program is Local Law 87 and it focus on commercial and mixed-use buildings and residential buildings. Local Law 87 focuses on energy audits and retro-commissioning. A complete energy audit and retro-commissioning need to be completed once every ten years through New York City Energy Efficiency Corporation (NYCEEC) (Green Buildings). This goes hand in hand with the 2013 New York City carbon challenge, which is in place to help reduce carbon emissions by 2025. "The New York City Carbon Challenge pledge has been taken by over 100 participants, accounting for over 500 million square feet of real estate, or more than 9 percent of citywide square footage" (The New York City). Twenty-one of those that have volunteered to participate in the carbon challenge intend to continue to cut their carbon emissions even further. They want to be able to cut by 50 percent from their current 30 percent that they have already met by 2025 (The New York City).

Twenty-one does not seem to be much, but for New York City it is important. Especially when that twenty-one makes up New York City's hotels, retail, hospitals, higher education facilities, and commercial owners. In 2017, New York City gave a similar challenge to commercial owners and tenants. There have been concerns raised about this challenge, similar to that of Seattle's Building Tune-up process. Many thought this may raise rent for residents in New York's already overpopulated city that already has been experiencing a housing crisis. Building owners did not see a reason for the upgrades, due to not being the recipients that would experience the benefits of lower energy costs, but would face the cost of replacing or improving current heating and cooling equipment.

The idea for this challenge came from the percentage of emissions and energy consumption that was from the vast array of commercial buildings that are in New York City. "Commercial buildings account for roughly 30 percent of New York City's emissions and the energy used in leased interior space accounts for between 40 to 60 percent of total energy consumption in a typical commercial office building" (NYC Carbon Challenge). The challenge to the commercial buildings is the exact same as those that took the New York City Carbon Challenge pledge. The commercial buildings must commit to a 50 percent carbon reduction by 2025 .

In comparison, Boulder, Colorado takes a different approach to the same problem. Boulder put into practice Boulder Building Performance Ordinance, Number 8071 Boulder Revised code Title 10 Chapter 7.7 in 2015. Their requirements are for "all existing buildings greater than 50,000 square feet, new buildings greater than 10,000 square feet, and all city buildings greater than 5,000 square feet" (Boulder Building Performance). Boulder, Colorado "has the goal of reducing overall emission by 80 percent by 2050 from a 2005 baseline" (Boulder Building Performance).

This is a lofty goal, and the way Boulder is managing its efficiency requirements in place, also differs from both Seattle and New York. They have their energy assessments and retro-commissioning on an ten-year schedule along with requiring one-time lighting upgrades. If the owner does pass the costs of the energy assessments and retro-commissioning to the tenants, then the owner needs to follow the City Manager Rules as per how to do so. "For energy assessment and retro-commissioning study: costs must by amortized over a 10 year period. For the required retro-commissioning measure implementation: costs must be amortized over the length of the predicted payback period (How-to Guide). This could be seen in a positive light for the renters of Boulder since rent prices, much like in other parts of the United States, are high and they will not be shouldering the full cost of the building tune-up from their landlord all at once.

\section{Conclusions}

For Boulder, Colorado their building tune-up ordinance has yielded positive results since the inception of their program. In 2017, Boulder achieved a "16 percent emissions reduction from its 2005 baseline, achieving the 2020 emissions reduction goal three years ahead of schedule" (Community Greenhouse). They know that they have more work to do to reach their goal of an 80 percent emissions reduction and have been creative by promoting programs related to energy efficiency, vehicle efficiency, renewable energy, and zero waste.

New York participants "have cut their annual emissions by 580,000 metric tons of carbon and are collectively saving almost \$190 million annually in lower energy" costs (The New York City). By the end of the New York City Carbon Challenge the participants "are on a projected track to reduce citywide emissions by $1,500,000$ metric tons of carbon dioxide equivalent and result in an estimated \$700 million in energy cost savings" (The New York City). For such a small percent of New York City's building owners to create such a large overall impact is outstanding. This shows that a small number of people can and do make a great impact when working towards a goal.

Boulder and New York City show that the various tune-up requirements per city and state can and do work and work well. There is also tentative proof that Seattle will follow a similar trend.

"The Seattle Office of Sustainability and Environment released its annual building energy performance data 
for over 3,300 properties reporting data through Seattle's Energy bench-marking program. Bench marked buildings showed a 2.7 percent decrease in energy consumption from 2014 to 2015, after adjusting for differences in weather" (Majersik).

Bench-marking is an important step because the data collected is used to help create a full picture of the building for the initial building "tune-up" and is through Seattle's Energy Bench-marking Program (SMC 22.920). This program requires owners of non-residential and multifamily buildings, that are 20,000 square feet or larger, to track their energy performance and report their results to Seattle on a yearly basis (Coven).

As a result of the data already collected from both Boulder and New York, it can be tentatively stated that the tune-up program for Seattle will have positive influences in the urban spaces and conservation. The tune-up process seems to be a great step for Seattle to help reduce its carbon footprint and at the same time give building owners another resource in which to help keep their buildings up to date with state and federal code and keep their buildings healthy. It is a little early to say if Seattle will be on par with Border, Colorado's 2020 emissions goals, but there is enough evidence to suggest that Seattle will create its own path in with the reduction of its carbon footprint, and will stay a major player in the green city movement.

\section{References}

“A Bill For An Act HB 1822.” House Of Representatives Twenty-Ninth Legislature, 2018 State Of Hawaii, 2018. Retrieved from https://www.capitol.hawaii.gov/session2018/bills/HB1822_.PDF

About Building Tune-Ups. Office of Sustainability and Environment. Retrieved September 9, 2018, from https://www.seattle.gov/environment/climate-change/building-energy/building-tune-ups/about-building-tun e-ups.

Assefa, S. (2018). Population \& Demographics. Seattle.gov, Office of Planning \& Community Development. Retrieved from www.seattle.gov/opcd/population-and-demographics

"Boulder Building Performance Efficiency Requirements." City of Boulder Colorado, City of Boulder, 2018, bouldercolorado.gov/sustainability/boulder-building-performance-efficiency-requirements

"Boulder Building Performance Program." Boulder Building Performance, City of Boulder, 2018, bouldercolorado.gov/sustainability/boulder-building-performance-home

“Community Greenhouse Gas Emissions." Community Greehouse Gas Emissions, City of Boulder Colorado, 2018, bouldercolorado.gov/boulder-measures/community-greenhouse-gas-emissions

Coven, J. F. (2017, January 25). Director's Rule 2016-01. Seattle: City of Seattle. Retrieved September 9, 2018 from https://www.seattle.gov/Documents/Departments/OSE/OSE_DIRECTORS_RULE_2016-01.pdf

Coven, J. F. (2018). Energy Benchmarking. Office of Sustainability \& Environment, Seattle.gov. Retrieved from www.seattle.gov/environment/climate-change/buildings-and-energy/energy-benchmarking

Data Access and Dissemination Systems (DADS). "United States Census Bureau." American FactFinder - Results, 1 July 2017, factfinder.census.gov/faces/nav/jsf/pages/community_facts.xhtml?src=bkmk

"Green Buildings \& Energy Efficiency." GBEE-Greener, Greater Buildings Plan, NYC Mayor's Office of Sustainability, 2018. www.nyc.gov/html/gbee/html/plan/plan.shtml

"Ensuring Fire Safety in Building Construction." Low-Income Housing Tax Credits | HUD USER, accessed December 3, 2018 www.huduser.gov/portal/pdredge/pdr-edge-trending-072417.html

"Joint Statement on Deadly Oakland Warehouse Fire | Office of the Mayor | Press Release." City of Philadelphia, 5 Dec. 2016, www.phila.gov/press-releases/mayor/joint-statement-on-deadly-oakland-warehouse-fire/

"How-to Guide for Boulder's Building Performance Ordinance Efficiency Requirements and Exemptions." City of Boulder, 2018, https://www-static.bouldercolorado.gov/docs/BPO_How_to_Guide_for_Boulder_2018_update-1-20180430 1144.pdf

“Indoor Air Facts No. 4 (Revised) Sick Building Syndrome.” United States Environmental Protection Agency, Feb. 1991. Accessed December 2018. https://www.epa.gov/sites/production/files/2014-08/documents/sick_building_factsheet.pdf

Majersik, C. (2017, April 28). March on Climate Action by Tackling Building Energy Efficiency. Retrieved September 9, 2018, from https://www.huffingtonpost.com/entry/march-on-climate-action-by-tackling-build ing-energy_us_590363e2e4b084f59b49f86c 
Mallory, S. (2018) Building Energy Efficiency and GHG Reduction 2015 Legislation. Director's Report and Recommendation, Version 3.

Marchesano, S. (2018). Northwest Real Estate Forum. Retrieved September 9, 2018, from https://www.gsblaw.com/northwest-real-estate-forum/seattle-commercial-building-tune-ups

"NYC Carbon Challenge for Commercial Owners and Tenants." GBEE-The New York City Carbon Challenge, $\begin{array}{lllll}\text { NYC Mayor's Office } & \text { Sustainability, }\end{array}$ www.nyc.gov/html/gbee/html/challenge/commercial-offices.shtml

"The New York City Carbon Challenge." GBEE-The New York City Carbon Challenge, NYC Mayor's Office of Sustainability, 2018, www.nyc.gov/html/gbee/html/challenge/nyc-carbon-challenges.html

Willmott, E. (2018, November 29). Tuning Up Seattle's Buildings. Retrieved September 9, 2018, from https://www.climatesolutions.org/article/1458665755-tuning-seattles-buildings

\section{Copyrights}

Copyright for this article is retained by the author(s), with first publication rights granted to the journal.

This is an open-access article distributed under the terms and conditions of the Creative Commons Attribution license (http://creativecommons.org/licenses/by/4.0/). 